Simbiosis Mutualisme Perpustakaan dengan Media Cetak sebagai Upaya Membudayakan Membaca dan Menulis bagi Masyrakat Muhammad Rohmadi

- Faktor Pengembangan dan Isu dalam Masalah Karier Pustakawan Masriyatun

Menguak Informasi via Alexa.com sebagai Evaluasi Menuju Optimalisasi

- Keberaksesan terhadap Perpustakaan dan Institusinya Wiji Suwarno

Profesionalisme Pustakawan dalam Layanan Informasi SriAnawati

Public Space dan Private Space: Posisi Strategis Perpustakaan dalam Mendukung

Pembelajaran Kolaboratif Purwani Istiana

Mewujudkan World-class Professionalism of Librarians di Era Library Mobile

Yuni Nurjanah

- Tantangan dan Kesiapan Pustakawan di Era Digital Dian Hapsari

Formulasi Strategi Membangun Eksistensi Perpustakaan Perguruan Tinggi

(Studi UPT Perpustakaan UNS Tahun 2015) RiahWiratningsih

Optimalisasi Perpustakaan Desa dalam Rangka Meningkatkan Pendidikan Masyarakat Bambang Hemanto

Optimalisasi Layanan Perpustakaan Perguruan Tinggi melalui Pemanfaatan Social

- Media Networking sebagai Media Komunikasi antara Perpustakaan dan Pemustaka Haryanto

Rekonstruksi Budaya Hukum Masyarakat dalam Pemulihan Pascakonflik Etnis Madura dan Melayu di Kabupaten Sambas 


\section{Jurnal \\ Pustaka Ilmiah \\ Jurnal Ilmiah UPT Perpustakaan UNS}

Jurnal Pustaka Ilmiah (JPI) sebagai media kreasi para pustakawan, guru, dosen, dan praktisi dalam pengembangan profesi secara berkelanjutan. Berbagai ide dan gagasan kreatif menjadi bahan kajian yang diimplementasikan dalam berbagai model pengembangan bahan pustaka, baik cetak maupun online. Kreativitas menjadi akar pengembangan ilmu pengetahuan sepanjang hayat dengan berbagai model pengembangan budaya literasi di perpustakaan. Keindahan dan kecermatan dalam sebuah tulisan ilmiah dan nonilmiah akan dapat direalisasikan secara nyata oleh sumber daya manusia untuk menghasilkan SDM yang unggul dan kreatif dengan membaca dan menulis untuk menyinari dunia. Budaya literasi menjadi upaya untuk pengembangan dan pemberdayaan perpustakaan sebagai pusat sumber belajar untuk mendukung tri dharma perguruan tinggi.

\section{SUSUNAN REDAKSI JURNAL PUSTAKA ILMIAH UPT PERPUSTAKAAN UNS}

Penanggung Jawab

Ketua Redaksi

Wakil Redaksi

Sekretaris

Penyunting Ahli
: Dr. Muhammad Rohmadi, M.Hum.

: Dra. Tri Hardiningtyas, M.Si.

: Haryanto, M.IP.

: Bambang Hermanto, S.Pd., M.IP., Henny Perwitosari, A.Md.

: 1. Dr. Muhammad Rohmadi, M.Hum. (Universitas Sebelas Maret);

2. Drs. Widodo, M.Soc.Sc. (Universitas Sebelas Maret);

3. Drs. Harmawan, M.Lib. (Universitas Sebelas Maret).

: Daryono, S.Sos., M.IP.; RiahWiratningsih, S.S., M.Si., Dinar Puspita Dewi, S.Sos., M.IP.; Sri Utari, S.E.

: Nurul H., A. Md.; Novi Tri Astuti, A.Md.

: Aji Hartono, A. Md.; Agus Sriyono, A.Md.; Aris Suprihadi, S.IP.

\section{DITERBITKAN OLEH UPT PERPUSTAKAAN UNS}

REDAKSI JURNAL PUSTAKA ILMIAH

Alamat: Jl. Ir. Sutami 36A Kentingan, Surakarta 57126

Telp./Fax.: (0271) 654311; email: jurnal.pustaka.ilmiah@gmail.com 


\section{PENGANTAR REDAKSI}

Salam pustaka. Dengan rasa syukur kepada allah swt. Segenap redaksi Jurnal Pustaka Ilmiah (JPI) mengucapkan banyak terima kasih kepada para penulis yang telah berkontribusi untuk penerbitan perdana JPI. Dengan terbitnya JPI ini berarti UPT Perpustakaan UNS telah memiliki media penulisan bagai para pustakawan, dosen, tenaga kependidikan, guru, dan praktisi untuk menuangkan ide dan gagasan kreatifnya secara tertulis.

Dalam penerbitan JPI perdana ini disajikan sepuluh tulisan antara lain: (1) Faktor Pengembangan dan Isu Dalam Masalah Karier Pustakawan (Masriyatun), (2) Menguak Informasi via Alexa.com sebagai Evaluasi Menuju Optimalisasi Keberaksesan terhadap Perpustakaan dan Institusinya (Wiji Suwarno), (3) Profesionalisme Pustakawan dalam Layanan Informasi (Sri Anawati), (4) Public Space dan Private Space: Posisi Strategis Perpustakaan dalam Mendukung Pembelajaran Kolaboratif (Purwani Istiana), (5) Mewujudkan World-class Professionalism of Librarians di Era Library Mobile (Yuni Nurjanah), (6) Tantangan dan Kesiapan Pustakawan di Era Digital (Dian Hapsari), (7) Formulasi Strategi Membangun Eksistensi Perpustakaan Perguruan Tinggi (Studi UPT Perpustakaan UNS Tahun 2015) (Riah Wiratningsih), (8) Optimalisasi Perpustakaan Desa dalam Rangka Meningkatkan Pendidikan Masyarakat (Bambang Hemanto), (9) Optimalisasi Layanan Perpustakaan Perguruan Tinggi melalui Pemanfaatan Social Media Networking sebagai Media Komunikasi antara Perpustakaan dan Pemustaka (Haryanto).

Akhirnya, redaksi JPI mengucapkan banyak terima kasih kepada Kepala UPT Perpustakaan UNS yang telah memberikan dukungan dan memfasilitasi untuk penerbitan JPI. Selain itu, ucapan terima kasih juga disampaikan kepada para penulis, tim redaksi, dan Yuma Pressindo, yang telah mempersiapkan dari awal sampai terbitnya JPI.

Desember 2015

Ketua Redaksi, 


\section{SAMBUTAN}

Dr. Muhammad Rohmadi, M.Hum.

Kepala UPT Perpustakaan UNS

\section{“Jadikalah tulisanmu sebagai cermin kehidupanmu di masa sekarang dan masa depan"}

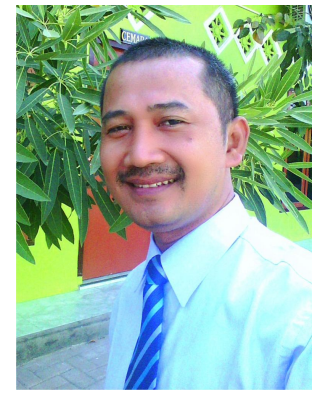

Selamat dan sukses atas diterbitkannya Jurnal Pustaka Ilmiah (selanjutnya disingkat JPI). Sambutan ini diberikan dalam rangka penerbitan perdana JPI. Jurnal ini sebagai media kreativitas dan pengembangan softskill para pustakawan, guru, dosen, dan praktisi untuk menuangkan ide dan gagasan dalam berbagai konteks kehidupan. Berbagai isu terkait dengan pengembangan perpustakan, pusat sumber belajar, pendidikan, dan budaya literasi akan menjadi topik-topik yang disajikan dalama jurnal ilmiah ini.

Diterbitkannya JPI sebagai bukti kepedulian UPT perpustakaan Ilmiah dalam rangka turut berpartisipasi untuk mengembangkan dan membudayakan literasi untuk para pustakawan dan civitas akademika di UNS dan luar UNS. Berbagai model pengembangan softskill menjadi alaternatif untuk membekali dan memperkuat jaringan kerja sama penulisan antarkelembagaan. Dengan demikian, kerja sama antarpustakawan dan pemustaka dapat diwujudkan dengan berbagai model dalam bidang literasi.

Penerbitan JPI sebagai upaya untuk memotivasi semua pustakawan menulis, baik ilmiah maupun nonilmiah. Para pustakawan harus menjadi pionir dalam bidang penulisan. Hal ini sebagai bentuk kepedulian dan keteladaan para pustakawan yang memproses, menyajikan, dan menikmati bahanbahan pustaka cetak dan noncetak di perpustakaan. Ketersedian bahan pustaka akan menjadi bahan paling nyata untuk dikembangkan dalam berbagai model perwujudan teknik peniulisan. Hal terpenting yang harus dimiliki oleh para pustakawan adalah semangat untuk berbagai pengetahuan melalui tulisan.

Kepedulian setiap sumber daya manusia kepada kelembagaan dapat dituangkan dalam berbagai model pengabdian, salah satunya adalah melalui tulisan. Berbagai ide dan gagasan dapat direalisasikan dengan berbagai model bentuk artikel jurnal, buku, modul, monograf, dan lain sebagainya. Para civitas akademika, guru, praktisi harus memiliki keterampilan menulis sebagai bentuk perwujudan pengembangan diri secara berkelanjutan. Berbagai tulisan dan referensi sudah disajikan tetapi masih sangat minim untuk diimplementasikan dalam kehidupan. Banyak orang pandai dalam berbicara tetapi masih sedikit yang menuangkan ide dan gagasannya dalam bentuk tulisan.

Akhirnya, keluarga besarUPT Perpustakaan UNS mengucapkan banyak terima kasih kepada Rektor, Wakil Rektor, pengelola JPI, penulis, dan semua pihak yang telah mendukung penerbitan perdana JPI. Semoga dengan diterbitkannya JPI ini dapat menjadi media untuk menulis para pustakawan, dosen, guru, dan praktisi dalam bidang iptek dan seni. Ucapan terima kasih juga diucapkan kepada percetakan Yuma Pressindo yang telah membantu mempersiapkan dari awal sampai terbitnya JPI ini. Akhirnya, semoga JPI dapat memberikan nilai kemaslahatan untuk umat.

“Berdiri kemudian berbaring sangatlah cepat tetapi tatkala sudah dituliskan akan menjadi kenangan yang taidak terlupakan sepanjang hayat”

Surakarta, Desember 2015 


\section{DAFTAR ISI \\ JURNAL PUSTAKA ILMIAH EDISI 1 VOLUME 1 TAHUN 2015}

Simbiosis Mutualisme Perpustakaan dengan Media Cetak sebagai Upaya Membudayakan Membaca dan Menulis bagi Masyrakat

Muhammad Rohmadi

Faktor Pengembangan dan Isu dalam Masalah Karier Pustakawan.

Masriyatun

Menguak Informasi via Alexa.com sebagai Evaluasi Menuju Optimalisasi Keberaksesan terhadap Perpustakaan dan Institusinya

Wiji Suwarno

Profesionalisme Pustakawan dalam Layanan Informasi

Sri Anawati

Public Space dan Private Space: Posisi Strategis Perpustakaan dalam Mendukung Pembelajaran Kolaboratif

Purwani Istiana

Mewujudkan World-class Professionalism of Librarians di Era Library Mobile

Yuni Nurjanah

Tantangan dan Kesiapan Pustakawan di Era Digital

Dian Hapsari

Formulasi Strategi Membangun Eksistensi Perpustakaan Perguruan Tinggi (Studi UPT Perpustakaan UNS Tahun 2015)

Riah Wiratningsih

Optimalisasi Perpustakaan Desa dalam Rangka Meningkatkan Pendidikan Masyarakat Bambang Hemanto

Optimalisasi Layanan Perpustakaan Perguruan Tinggi melalui Pemanfaatan Social Media Networking sebagai Media Komunikasi antara Perpustakaan dan Pemustaka Haryanto 


\title{
TANTANGAN DAN KOMPETENSI PUSTAKAWAN DI ERA DIGITAL
}

\author{
Dian Hapsari ${ }^{1}$ \\ dianhapsariku@gmail.com
}

\begin{abstract}
ABSTRAK
Tantangan keberadaan perpustakaan di era digital semakin kompleks. Tantangan tersebut, antara lain: 1) semakin banyaknya informasi; 2) mengelola berbagai macam bentuk bahan pustaka; 3) semakin kompleksnya sumber-sumber informasi; 4) pengguna perpustakaan berupa generasi digital. Agar dapat tetap eksis keberadaannya perpustakaan harus berperan aktif menunjukkan fungsinya sebagai pusat informasi, kolaborasi, komunikasi, dan penelitian. Pustakawan sebagai salah satu komponen utama di perpustakaan diharapkan memiliki kompetensi yang memadai dan terus ditingkatkan dalam menghadapi persaingan di era digital ini.
\end{abstract}

Kata kunci: era digital, tantangan, kompetensi, pustakawan

\section{PENDAHULUAN}

Tantangan keberadaan perpustakaan di era digital semakin bertambah kompleks. Perpustakaan tidak lagi hanya bersaing dengan lembaga-lembaga penyedia informasi yang sejenis. Akan tetapi, persaing yang paling mengancam kedudukan dan peran perpustakaan saat ini adalah lautan informasi yang terus berkembang dinamis dan tak terbatas.

Agar keberadaannya dapat tetap eksis, perpustakaan mau tidak mau harus mengikuti tuntutan perkembangan zaman. Di era digital, termasuk juga kehadiran internet, menyebabkan peran perpustakaan mengalami banyak perubahan. Perpustakaan, khususnya perpustakaan perguruan tinggi tidak lagi hanya sebagai lembaga yang mengumpulkan bukubuku dan menunggu kehadiran pemustaka datang ke perpustakaan untuk menggunakan koleksi yang dimiliki oleh perpustakaan, tetapi juga harus berperan aktif menunjukkan fungsinya sebagai pusat informasi, kolaborasi, komunikasi, dan penelitian.

Agar dapat melakukan hal-hal tersebut, perpustakaan seharusnya mempunyai sumber daya manusia yang memadai. Pustakawan sebagai salah satu komponen utama di perpustakaan dituntut untuk memiliki dan meningkatkan berbagai kompetensi yang dimiliki agar perpustakaan dapat terus eksis. Kreativitas, ide, dan upaya-upaya yang dilakukan oleh seorang pustakawan merupakan salah satu faktor penentu keberhasilan sebuah perpustakaan. Untuk itu, kemampuan dan keterampilan seorang pustakawan harus selalu ditingkatkan dan diperbaharui. Kemampuankemampuan dasar pustakawan, seperti katalogisasi, klasifikasi, tajuk subjek, dan sebagainya tidak dihilangkan, tetapi harus diupgrade, disesuaikan dengan perkembangan era digital. Selain itu, ditambah lagi dengan kemampuan lain, seperti mengorganisasi berbagai jenis bahan pustaka dan kemampuan menelusuri sumber-sumber informasi melalui teknologi informasi

Pengguna potensial perpustakaan pada saat ini adalah mereka yang dikenal sebagai “net generation". Salah satu karakteristik net generation yang paling menonjol adalah mereka sudah terbiasa dengan teknologi informasi sehingga memiliki kemampuan yang memadai

1 Pustakawan di Fakultas Hukum UNS. 
dalam memanfaatkannya untuk memenuhi kebutuhan informasi yang dibutuhkannya. Dengan kemampuan yang dimiliki, net generation lebih memilih menggunakan media internet untuk mencari informasi yang mereka butuhkan dibandingkan mencarinya di perpustakaan. Di sinilah tantangan bagi para pustakawan di era digital untuk memberikan pelayanan yang baik bagi pemustakanya, khususnya net generation tersebut.

Berdasarkan penjelasan diatas, rumusan masalah artikel ini adalah tantangan apa saja yang dihadapi oleh pustakawan di era digital dan kompetensi apa saja yang harus dimiliki oleh pustakawan di era digital?

\section{PEMBAHASAN}

\section{Pustakawan di Era Digital}

Dalam lima hukum dasar perpustakaan yang dikemukakan oleh Ranganathan, ${ }^{2}$ hukum kelima adalah library is growing organism. This law focused more on the need for internal change than on changes in the environment itself. Dr. Ranganathan argued that library organizations must accommodate growth in staff, the physical collection, and patron use. This involved allowing for growth in the physical building, reading areas, shelving, and in space for the catalog.

Hal ini berartikeberadaan perpustakaan akan terus berkembang dinamis mengikuti perubahan, termasuk juga di era digital seperti saat ini. Hadirnya teknologi informasi di perpustakaan, termasuk internet telah membuat perpustakaan berubah dalam banyak hal. Misalnya saja, untuk layanan yang awalnya bersifat manual, perlahan kini mulai beralih menuju otomatisasi. Selain itu, koleksi perpustakaan yang awalnya berupa koleksi cetak, seiring dengan hadirnya internet, koleksi perpustakaan juga meliputi koleksi digital, yang membutuhkan keahlian khusus untuk mengelolanya. Agar dapat terus berkembang, semua komponen di perpustakaan

2 Ranganathan, S. R.. 1988. The Five Laws of Library Science, (Sarada Ranganathan Endowment for Library Sci). harus selaras dalam bekerja. Faktor sumber daya manusia dalam hal ini adalah pustakawan, mau tidak mau harus berperan aktif mengikuti perkembangan masyarakat.

Kemampuan pustakawan untuk berubah dan beradaptasi sesuai dengan perkembangan masyarakat menjadi salah satu hal yang penting. Di era digital ini, pustakawan tidak lagi hanya duduk menunggu pemustaka datang ke perpustakaan memanfaatkan koleksi yang dimiliki, akan tetapi saat ini pustakawan diharapkan juga dapat berperan aktif sebagai jembatan/fasilitator antara sumber-sumber informasi dengan pemustaka.

Pemustaka di era digital ini adalah mereka yang dikenal sebagai internet generation atau net generation. Tapscott ${ }^{3}$ mengemukakan karakteristik net generation sebagai berikut:

\section{Freedom (kebebasan)}

Net generation menginginkan kebebasan. Adanya internet membuat net generation memiliki kebebasan untuk selalu dapat memilih apa yang akan dilakukannya, ingin menjadi siapa, dan sebagainya.

\section{Customization/personalize}

Net generation suka mengubah hal yang sudah standar menjadi sesuai dengan dirinya (personalize) dan menjadikan miliknya.

\section{Scrutiny}

Karakteristik yang berkaitan dengan sikap kritis untuk membedakan informasi yang terpercaya (reliable) dan yang tidak. Net generation suka mengkaji informasi apapun dengan saksama, termasuk asal-usul sumber informasi tersebut. Hal ini dikarenakan mereka dekat internet dan memiliki pandangan alternatif tentang beragam informasi yang ada di internet.

\section{Integrity}

Walaupun tumbuh dan berkembang di era kemajuan teknologi informasi, net generation

3 Tapscott, Don. 2009. "Grown Up Digital: How NetGeneration is Changing Your World". Diakses pada 1 Agustus 2015, dari http://dontapscott.com/books/grown-up-digital. 
tetap memiliki integritas yang kuat, sadar, dan bertanggung jawab atas apa yang dilakukan. Mereka menekankan pada kejujuran dan keterbukaan.

\section{Collaboration}

Net Generation merupakan generasi yang terbiasa melakukan kolaborasi (collaboration), berjejaring dengan berbagai pihak. Umumnya dilakukan melalui jejaring sosial, seperti facebook, twitter, instagram, dan sebagainya untuk kepentingan upgrade informasi yang dimilikinya.

\section{Entertainment}

Internet memberikan fungsi hiburan untuk menyenangkan diri secara online. Net generation mudah dalam memperoleh hiburan dan berita-berita paling up to date dalam waktu yang singkat. Hal ini juga berarti bahwa net generation biasa "mencampur" hiburan dengan pekerjaan.

\section{Speed}

Net Generation fokus terhadap kecepatan dan respons instan karena adanya kecanggihan teknologi informasi yang dapat diakses tanpa batasan ruang dan waktu sehingga penyebaran informasi dapat dilakukan secara singkat.

\section{Innovationn}

Yang terpenting darii kemunculan net generation adalah adanya inovasi yang bersifat dinamis, yaitu adanya ide-ide baru, temuantemuan baru, dan bahkan masa depan baru.

\section{Tantangan dan Kompetensi Pustakawan di Era Digital}

Di era digital ini, tantangan yang dihadapi oleh sebuah perpustakaan, antara lain adanya informasi tanpa batas, semakin beragamnya bahan pustaka, semakin kompleksnya sumbersumber informasi yang ada, serta pengguna perpustakaan pada saat ini adalah para net generation. Untuk menjawab berbagai tantangan tersebut, maka dibutuhkan seorang pustakawan profesional.
Pustakawan merupakan sebuah profesi. Sebagaimana profesi lainnya, pustakawan merujuk pada pekerjaan atau jabatan yang menuntut keahlian, tanggung jawab, dan kesetiaan. Suatu profesi tidak bisa dilakukan oleh sembarang orang yang tidak dilatih atau dipersiapkan untuk melakukan profesi tersebut. Sulistyo-Basuki ${ }^{4}$ menjelaskan mengenai pustakawan sebagai profesi mempunyai syarat, antara lain:

1. Adanya sebuah asosiasi atau organisasi keahlian.

2. Adanya struktur dan pola pendidikan yang jelas.

3. Adanya kode etik.

4. Adanya tingkat kemandirian.

5. Profesi pustakawan berorientasi pada jasa.

Sementara itu, Undang-Undang nomor 43 TAHUN 2007 tentang perpustakaan menyebutkan bahwa pustakawan adalah seseorang yang memiliki kompetensi yang diperoleh melalui pendidikan dan/atau pelatihan kepustakawanan, serta mempunyai tugas dan tanggung jawab untuk melaksanakan pengelolaan dan pelayanan perpustakaan.

Berdasarkan dua definisi di atas, maka yang disebut profesi haruslah berlandaskan pada jenjang pendidikan formal dan memiliki etika serta tanggung jawab yang menjadi panduan dalam menjalankan profesi tersebut. Profesional pustakawan berkaitan dengan adanya kompetensi karena pada hakikatnya pustakawan dikatakan profesional apabila dia memiliki kompetensi di bidang perpustakaan. Kamus Besar Bahasa Indonesia ${ }^{5}$ menyebutkan definisi kompetensi sebagai kewenangan (kekuasaan) untuk menentukan (memutuskan sesuatu).

Dalam tulisan dari Assoc. Prof. Dr. Christopher Soo-Guan $\mathrm{Khoo}^{6}$ yang berjudul

4 Sulistyo-Basuki. Pengantar Ilmu Perpustakaan, (Jakarta: Gramedia, 1991).

5 Tim Penyusun. Kamus Besar Bahasa Indonesia, (Jakarta: Gramedia Pustaka Utama, 2012).

6 Soo-Guan Khoo, Christopher. "Competencies for New Era 
Competencies for New Era Librarians and Information Proffesionals, menyebutkan kompetensi pustakawan di era teknologi informasi secara garis besar meliputi sembilan hal, meliputi:

1. Traditional LIS skills, extended to the electronic environment

2. Information management

3. IT-related skills

4. Transferable/generic skills

5. Teaching, training and coaching

6. Management and leadership

7. Entrepreneurship

8. Attitudes and personal traits

9. Other skills/knowledges

Sementara itu, berdasarkan Standar Kompetensi Kinerja Indonesia ${ }^{7}$ bidang perpustakaan, pengetahuan, keterampilan, dan sikap kerja pustakawan diwujudkan dalam tiga kelompok unit kompetensi, yaitu kelompok kompetensi umum, kelompok kompetensi inti dan kelompok kompetensi khusus. Penjelasannya masing-masing sebagai berikut.

1. Kompetensi Umum

Kompetensi Umum adalah kompetensi dasar yang harus dimiliki oleh setiap pustakawan, yang diperlukan untuk melakukan tugas-tugas perpustakaan, meliputi:

a. Mengoperasikan komputer tingkat dasar

b. Menyusun rencana kerja perpustakaan

c. Membuat laporan kerja perpustakaan

2. Kompetensi Inti

Kompetensi inti adalah kompetensi fungsional yang harus dimiliki oleh setiap pustakawan dalam menjalankan tugas-tugas perpustakaan. Kompetensi inti mencakup unit-unit kompetensi yang dibutuhkan untuk mengerjakan tugas-tugas inti dan wajib dikuasai oleh pustakawan. Kompetensi inti, meliputi:

Librarians and Information Proffesionals". Diakses pada 1 Agustus 2015, dari www.ibrarian.net/.

7 Standar Kompetensi Kinerja Nasional Indonesia Tahun 2012 Bidang Perpustakaan a. Melakukan seleksi bahan perpustakaan.

b. Melakukan pengadaan bahan perpustakaan.

c. Melakukan pengatalogan deskriptif.

d. Melakukan pengatalogan subjek.

e. Melakukan perawatan bahan perpustakaan.

f. Melakukan layanan sirkulasi.

g. Melakukan layanan referensi.

h. Melakukan penelusuran informasi sederhana.

i. Melakukan promosi perpustakaan.

j. Melakukan kegiatan literasi informasi.

k. Memanfaatkan jaringan internet untuk layanan perpustakaan.

3. Kompetensi Khusus

Kompetensi khusus merupakan kompetensi tingkat lanjut yang bersifat spesifik, meliputi:

a. Merancang tata ruang dan perabot perpustakaan.

b. Melakukan perbaikan bahan perpustakaan.

c. Membuat literatur sekunder.

d. Melakukan penelusuran informasi kompleks.

e. Melakukan kajian perpustakaan.

f. Membuat karya tulis ilmiah.

\section{ANALISIS}

Kehadiran teknologi informasi, khususnya internet telah membawa perubahan di segala bidang, termasuk perpustakaan. Sebagaimana diutarakan oleh Ranganathan library is growing organism, maka keberadaan perpustakaan akan selalu berkembang mengikuti perkembangan zaman. Ketika memasuki era digital, di mana informasi menjadi lautan tak terbatas dan pengguna perpustakaan adalah mereka yang dikenal sebagai net generation, maka perpustakaan menghadapi berbagai macam tantangan baru yang semakin kompleks. Adapun beberapa tantangan yang dihadapi oleh perpustakaan antara lain: 


\section{Semakin banyaknya informasi}

Di era digital, informasi melimpah ruah. Internet sering diibaratkan sebagai hutan belantara yang sangat luas. Berbagai informasi tersedia di dalamnya dan bisa diakses oleh siapa saja dan kapan saja dengan cepat. Akibat informasi yang melimpah ruah ini, sulit untuk memutuskan mana informasi yang berguna dan penting. Tingkat validitas kebenaran suatu informasi pun seringkali menjadi samar. Kemampuan menyaring, memadukan, dan menyajikan informasi yang sesuai dengan kebutuhan pemustaka menjadi salah satu hal yang penting dimiliki oleh pustakawan.

2. Mengelola berbagai macam bentuk bahan pustaka

Koleksi bahan pustaka yang ada saat ini tersedia dalam berbagai format. Baik format digital maupun nondigital, setiap bahan pustaka mempunyai "usia" penggunaan. Akan tetapi, ketika bahan pustaka disimpan dalam format digital, maka "usia" penggunaan bahan pustaka tersebut akan lebih cepat karena dengan teknologi informasi yang terus berkembang, format penyimpanan juga akan terus berubah mengikuti teknologi. Kemampuan pustakawan untuk mengelola berbagai macam bahan pustaka ini menjadi salah satu hal yang penting sehingga diharapkan bahan pustaka dapat terus digunakan.

3. Semakin kompleknya sumber-sumber informasi

Informasi di era digital seringkali berasal dari berbagai macam sumber. Pustakawan selain dituntut untuk dapat menggunakan kemampuannya dalam menelusuri sumbersumber informasi, mereka juga diharapkan dapat mengajarkan kemampuan tersebut kepada pemustaka. Layanan bimbingan kepada pemustaka ini penting dilakukan.

4. Pengguna perpustakaan berupa generasi digital

Generasi digital atau yang lebih dikenal dengan internet generation atau net generation memiliki karakteristik yang berbeda dari generasi sebelumnya. Dalam berbagai survei yang telah dilakukan, pola pencarian informasi generasi digital ini juga berbeda dari generasi sebelumnya. Generasi ini sudah terbiasa menggunakan teknologi informasi, bersikap lebih kritis aktif, dan cenderung menginginkan layanan perpustakaan yang serba cepat dan seketika. Untuk dapat menarik net generation, perpustakaan perlu melakukan pengembangan perpustakaan dari sisi teknologi informasi, fasilitas fisik, koleksi, maupun layanan perpustakaan.

Berbagai tantangan yang sudah dijelaskan di atas membuat perpustakaan sebagai pusat informasi harus selalu berbenah diri. Kehadiran seorang pustakawan profesional sangat dibutuhkan. Berdasarkan penjelasan mengenai kompetensi pustakawan, maka pada era digital ini kompetensi yang dibutuhkan pustakawan, meliputi:

5. Kemampuan mencari dan menggunakan sumber-sumber informasi

Merupakan kemampuan untuk menemukan informasi dengan menggunakan teknologi informasi, seperti internet. Sumber informasi saat ini tidak hanya berupa buku, jurnal, majalah, dan koran dalam bentuk tercetak, tetapi juga termasuk online media, seperti e-book dan e-journal.

6. Kemampuan melakukan pengembangan koleksi

Koleksi perpustakaan di era digital tidak hanya berbentuk tercetak, seperti buku teks, majalah, dan jurnal, tetapi juga meliputi koleksi dalam bentuk online, seperti jurnal, buku, dan majalah yang jumlahnya tidak terhitung.

7. Kemampuan mengelola informasi penyimpanan dan temu kembali informasi.

Merupakan kemampuan pustakawan dalam mengelola sumber-sumber informasi yang semakin hari semakin banyak jumlahnya. Termasuk juga menyimpan dan menemukan 
kembali koleksi yang dimilikioleh perpustakaan, baik koleksi fisik maupun koleksi online. Dengan banyaknya informasi yang tersedia di era digital ini, pustakawan dituntut untuk dapat mengelola berbagai jenis informasi tersebut, menemukannya kembali ketika dibutuhkan sekaligus menyajikan sesuai dengan kebutuhan pemustaka

8. Kemampuan berkomunikasi

Merupakan kemampuan pustakawan berkomunikasi dengan rekan sejawat, seprofesi, ataupun dengan bidang lain. Di era digital ini, kolaborasi dan networking merupakan hal yang sangat penting. Dengan komunikasi yang baik, maka kolaborasi dan networking akan dapat dilakukan, baik antara pustakawan dengan pustakawan atau pustakawan dengan bidang lain, seperti dosen, IT, dan lainnya. Kemampuan pustakawan meyediakan data, menganalisis, dan menyajikan data ketika presentasi atau kemampuan menuangkan ide atau gagasan dalam bentuk tulisan juga termasuk dalam berkomunikasi kemampuan pustakawan.

Selain penjelasan di atas, secara keseluruhan perpustakaan juga tetap harus mengembangkan diri sesuai dengan kebutuhan net generation, baik kebutuhan fisik, seperti fasilitas dan koleksi maupun kebutuhan nonfisik, misalnya saja menyediakan layanan yang sesuai dengan kebutuhan net generation.

\section{PENUTUP}

Tantangan keberadaan perpustakaan di era digital semakin bertambah kompleks. Adapun beberapa tantangan yang dihadapi ,antara lain adanya informasi yang tanpa batas, semakin beragamnya bahan pustaka, semakin kompleksnya sumber-sumber informasi yang ada, serta pengguna perpustakaan pada saat ini adalah para net generation. Agar perpustakaan dapat eksis sebagai pusat informasi, kolaborasi, dan penelitian, perpustakaan haruslah mempunyai sumber daya manusia yang memadai. Pustakawan sebagai salah satu komponen penting di perpustakaan diharapkan memiliki dan meningkatkan berbagai kompetensi.

Kreativitas, ide, dan upaya-upaya yang dilakukan oleh seorang pustakawan merupakan salah satu faktor penentu keberhasilan sebuah perpustakaan. Pustakawan yang profesional tentu saja memiliki berbagai kompetensi yang dapat digunakan untuk menjawab berbagai tantangan yang ada. Dengan demikian, perpustakaan dapat menjalankan fungsinya dengan maksimal di era digital.

\section{DAFTAR PUSTAKA}

Ranganathan, S. R.. 1988. The Five Laws of Library Science (Sarada Ranganathan Endowment for Library Sci.

Soo-Guan Khoo, Christopher. "Competencies for new era librarians and information proffesionals". Diakses pada 1 Agustus 2015, dari www.ibrarian.net/.

Standar Kompetensi Kinerja Nasional Indonesia Tahun 2012 Bidang Perpustakaan.

Sulistyo-Basuki.1991. Pengantar Ilmu Perpustakaan. Jakarta: Gramedia.

Tim Penyusun. 2012. Kamus Besar Bahasa Indonesia. Jakarta: Gramedia Pustaka Utama.

Undang-Undang Nomor 43 Tahun 2007 tentang Perpustakaan. 